\title{
Cover crop management in a Sauvignon blanc/Ramsey vineyard in the semi- arid Olifants River Valley, South Africa. 1. Effect of management practices on selected grass and broadleaf species
}

\author{
J.C. Fourie ${ }^{1 *}$, P.J.E. Louw ${ }^{1 * *}$ and G.A. Agenbag ${ }^{2}$ \\ (1) ARC Infruitec-Nietvoorbij***, Private Bag X5026, 7599 Stellenbosch, South Africa \\ (2) Department of Agronomy, Private Bag X1, 7152 Matieland (Stellenbosch), South Africa
}

Submitted for publication: December 2004

Accepted for publication: October 2005

Key words: Cover crops, water requirements, re-establishment, management practices, weed control, grapevines.

This trial was conducted over a period of ten years on a sandy soil in a Sauvignon blanc/Ramsey vineyard in Lutzville $\left(31^{\circ} 35\right.$ 'S, $\left.18^{\circ} 52^{\prime} \mathrm{E}\right)$, situated in the semi-arid Olifants River Valley of the Western Cape. Twenty-three treatments were applied. Eight cover crop species that received the same amount of fertilizer were controlled chemically at the end of August or at the end of November. Two treatments were also applied in which Avena sati$v a$ L. v. Saia ('Saia' oats) and Vicia dasycarpa Ten. (grazing vetch) were controlled mechanically during bud break. In addition to these eighteen treatments, two fertiliser application rates were applied to 'Saia' oats and grazing vetch. A mechanically cultivated control in which no cover crop was sown was included in the trial. Secale cereale L v. Henog and Ornithopus sativus L. v. Emena produced, on average, the highest amount of dry matter at the end of August (3.29 t/ha and 3.06 t/ha, respectively) after receiving on average $278 \mathrm{~mm}$ of water, of which $172 \mathrm{~mm}$ was supplied by means of a micro-sprinkler irrigation system. The average dry matter produced by Medicago truncatula Gaertn. v. Paraggio and 'Saia' oats at the end of August was not significantly lower than that of the firstmentioned two species. Under conditions of this experiment, it seemed that $P$ and $K$ at a concentration of $10 \mathrm{mg} / \mathrm{kg}$ and $78 \mathrm{mg} / \mathrm{kg}$, respectively, in the top $300 \mathrm{~mm}$ soil layer supplied the needs of grazing vetch. Saia oats performed poorly unless $30 \mathrm{~kg} \mathrm{P,} 30 \mathrm{~kg} \mathrm{~K}$ and $42 \mathrm{~kg} \mathrm{~N}$ were applied during establishment and the early growing phase. All the species, except $M$. truncatula Gaertn v. Parabinga, produced additional fibre from September to the end of November following a dry winter (rain and irrigation totaling $201 \mathrm{~mm}$ ), while none produced additional fibre if the water supply was luxurious up to the end of August (rain and irrigation totaling $364 \mathrm{~mm}$ ). The cover crops did not produce enough seeds to re-establish successfully over a period of five years. It will, however, be possible to reduce the seeding density of grazing vetch (40\% after two seasons) and the two $M$. truncatula varieties (20\% after five seasons) if the species were left to ripen their seeds.

The use of cover crops in vineyards has many advantages, inter alia, reduction of water runoff and erosion (Louw \& Bennie, 1992), restriction of evaporation from the soil surface (Van Huyssteen et al., 1984), soil water conservation (Buckerfield \& Webster, 1996) reduction of temperature fluctuations in the soil (Van Huyssteen et al., 1984), as well as being a non-specific method of weed control (Van Huyssteen et al., 1984; Fourie et al., 2001). A selection of species suitable as cover crops in the different grapevine regions is required to enable producers to apply this environment-friendly practice in a sustainable manner, as part of an integrated production strategy (Fourie et al., 2001). Fourie et al. (2001) indicated that four grain species, four subterranean clover species, four Medicago (medic) species, three Vicia (vetch) species and Ornitopus sativus L. v. Emena (pink Seradella) could be considered as cover crops on the sandy soils of the warm and semi-arid Olifants River Valley in the winter rainfall region of South Africa.

This study was conducted to determine the effect of different cover crop management practices on eight selected cover crop species on a sandy soil in the Olifants River Valley. This was done to supply guidelines for sustainable cover crop management in vineyards on the sandy soils of the semi-arid Olifants River Valley.

\section{MATERIALS AND METHODS}

\section{Experiment vineyard}

The trial was conducted in a Sauvignon blanc/Ramsey vineyard trained on a hedge trellis system (Archer \& Booysen, 1987) and established on a sandy soil (Table 1) at the Nietvoorbij experiment farm in Lutzville. The vines were spaced $1.5 \mathrm{~m}$ in the row and $3.0 \mathrm{~m}$ between rows. The soil was analysed for $\mathrm{pH}(1.0 \mathrm{M}$

*Corresponding author: E-mail address: FourieJ@arc.agric.za

**Present address: EXSA, P.O. Box 1000, 7599 Stellenbosch, Republic of South Africa

***The Fruit, Vine and Wine Research Institute of the Agricultural Research Council

Acknowledgements: The authors thank the ARC, Winetech and the Dried Fruit Technical Services for financial support, and the staff of the Soil Science Section of ARC Infruitec-Nietvoorbij for technical support. This study forms part of a PhD (Agric) dissertation, at the University of Stellenbosch. 
$\mathrm{KCl}$ ), $\mathrm{P}$ and $\mathrm{K}$ (Bray no 2), exchangeable cations, namely $\mathrm{K}, \mathrm{Ca}$, $\mathrm{Mg}$ and $\mathrm{Na}$ (extracted with $0.2 \mathrm{M}$ ammonium acetate) and organic matter by means of the Walkley-Black method (The Non-affiliated Soil Analysis Work Committee, 1990). Lutzville (31 ${ }^{\circ} 35^{\prime}$ S, $18^{\circ} 52^{\prime} \mathrm{E}$ ) is situated in the semi-arid Olifants River Valley of the Western Cape and receives an average annual rainfall of $139 \mathrm{~mm}$, of which approximately $70 \%$ precipitates during the winter months (April to August).

The vineyard was irrigated by means of micro-sprinklers with a $360^{\circ}$ wetting pattern, delivering $25.7 \mathrm{~L} / \mathrm{h}$, and mounted three meters apart on the irrigation line in the upright position. The irrigation of the cover crops was scheduled in accordance with the guidelines supplied by Fourie et al. (2001), depending on the availability of water during winter (Table 2). In the Olifants River Valley $1210 \mathrm{~mm}$ of water per hectare per annum is allocated for irrigation purposes. For the duration of the study this quota was mostly reduced during October, depending on the water level of the Olifants dam that supplies the valley with water for drinking, mining and agricultural purposes. This reduction frequently amounted to as much as $40 \%$ of the above-mentioned allocation, restricting the water available for the irrigation of the cover crops during winter. Maintenance work on the irrigation canal during winter also caused irrigation water to be unavailable from the beginning of May until the end of June for a fortnight at a time, with one week in between during which the canal would be operational. This continued from July to August, but the operational periods in between were of a fortnight's duration. The abovementioned restrictions complicated irrigation scheduling for the cover crops and caused the total amount of irrigation that could be applied to vary considerably between years. For example, to

TABLE 1

Analyses of the sandy soil in Lutzville determined before the treatments commenced (sampled March 1993).

\begin{tabular}{|c|c|c|c|c|c|c|c|c|c|c|c|c|}
\hline \multirow{2}{*}{$\begin{array}{l}\text { Soil depth } \\
(\mathrm{mm})\end{array}$} & \multirow{2}{*}{$\begin{array}{l}\text { Clay } \\
(\%)\end{array}$} & \multirow{2}{*}{$\begin{array}{l}\text { Silt } \\
(\%)\end{array}$} & \multirow{2}{*}{$\begin{array}{c}\text { Sand } \\
(\%)\end{array}$} & \multirow{2}{*}{$\begin{array}{c}\mathbf{p H} \\
(\mathbf{K C I})\end{array}$} & \multirow{2}{*}{$\begin{array}{c}\text { Electrical } \\
\text { conductivity } \\
\left(\mathbf{m S} . \mathbf{m}^{-1}\right)\end{array}$} & \multirow{2}{*}{$\begin{array}{c}\text { Organic } \\
\text { C }(\%)\end{array}$} & \multirow{2}{*}{$\begin{array}{c}P \\
(\mathrm{mg} / \mathrm{kg})\end{array}$} & \multirow{2}{*}{$\begin{array}{c}\mathrm{K} \\
(\mathrm{mg} / \mathrm{kg})\end{array}$} & \multicolumn{4}{|c|}{ Exchangeable cations $(\mathrm{cmol}(+) / \mathrm{kg})$} \\
\hline & & & & & & & & & $\mathrm{Ca}$ & Mg & $\mathbf{K}$ & $\mathrm{Na}$ \\
\hline $0-300$ & 0.01 & 1.43 & 98.56 & 5.9 & 9 & 0.13 & 15.80 & 111 & 0.87 & 0.46 & 0.29 & 0.06 \\
\hline $300-600$ & 0.01 & 1.20 & 98.79 & 5.8 & 6 & 0.10 & 8.75 & 96 & 0.72 & 0.44 & 0.26 & 0.09 \\
\hline
\end{tabular}

\section{TABLE 2}

Total amount of water (rainfall and irrigation) received each week from the beginning of April to the end of August, measured over a period of ten years.

\begin{tabular}{|c|c|c|c|c|c|c|c|c|c|c|c|c|}
\hline \multirow{2}{*}{ Month } & \multirow{2}{*}{ Date } & \multicolumn{10}{|c|}{ Total water $(\mathbf{m m})$} & \multirow[b]{2}{*}{ Average } \\
\hline & & 1993 & 1994 & 1995 & 1996 & 1997 & 1998 & 1999 & 2000 & 2001 & 2002 & \\
\hline April & $1-7$ & 29 & 12 & 0 & $25^{1}$ & 2 & $16^{1}$ & 0 & 0 & 9 & 2 & 9 \\
\hline April & $8-14$ & 39 & $18^{1}$ & $19^{1}$ & 24 & $42^{1}$ & 32 & 0 & $8^{1}$ & $24^{1}$ & $27^{1}$ & 23 \\
\hline April & $15-21$ & 4 & 12 & 32 & 22 & 21 & 36 & $52^{1}$ & 9 & 16 & 21 & 23 \\
\hline April & $22-28$ & 0 & 18 & 0 & 0 & 2 & 0 & 23 & 18 & 18 & 23 & 10 \\
\hline April/May & $29-5$ & $29^{1}$ & 18 & 5 & 34 & 21 & 5 & 15 & 8 & 25 & 16 & 18 \\
\hline May & $6-12$ & 20 & 16 & 9 & 0 & 0 & 16 & 15 & 23 & 16 & 25 & 14 \\
\hline May & $13-19$ & 16 & 16 & 1 & 24 & 0 & 3 & 25 & 23 & 21 & 37 & 17 \\
\hline May & $20-26$ & 22 & 7 & 34 & 18 & 67 & 0 & 4 & 0 & 26 & 12 & 19 \\
\hline May/June & $27-2$ & 29 & 0 & 0 & 24 & 4 & 5 & 0 & 1 & 0 & 24 & 9 \\
\hline June & $3-9$ & 16 & 10 & 4 & 13 & 13 & 8 & 23 & 0 & 12 & 2 & 10 \\
\hline June & $10-16$ & 15 & 0 & 5 & 7 & 5 & 0 & 2 & 19 & 32 & 33 & 12 \\
\hline June & $17-23$ & 16 & 6 & 0 & 8 & 5 & 0 & 6 & 6 & 25 & 32 & 10 \\
\hline June & $24-30$ & 4 & 26 & 0 & 0 & 27 & 23 & 1 & 16 & 23 & 32 & 15 \\
\hline July & $1-7$ & 2 & 0 & 5 & 24 & 0 & 2 & 24 & 16 & 39 & 0 & 11 \\
\hline July & $8-14$ & 11 & 0 & 0 & 8 & 0 & 0 & 0 & 10 & 11 & 16 & 5 \\
\hline July & $15-21$ & 9 & 32 & 9 & 0 & 0 & 3 & 7 & 19 & 36 & 3 & 12 \\
\hline July & $22-28$ & 13 & 20 & 54 & 13 & 0 & 25 & 4 & 0 & 0 & 6 & 13 \\
\hline July/August & $29-4$ & 10 & 0 & 5 & 0 & 27 & 2 & 56 & 3 & 0 & 5 & 11 \\
\hline August & $5-11$ & 20 & 4 & 7 & 39 & 0 & 24 & 3 & 39 & 3 & 0 & 14 \\
\hline August & $12-18$ & 0 & 0 & 0 & 0 & 48 & 2 & 0 & 0 & 7 & 6 & 6 \\
\hline August & $19-25$ & 20 & 48 & 13 & 0 & 0 & 0 & 11 & 2 & 8 & 3 & 10 \\
\hline August & $26-31$ & 0 & 0 & 0 & 21 & 9 & 0 & 1 & 2 & 13 & 17 & 6 \\
\hline Total & & 322 & 263 & 199 & 301 & 293 & 201 & 272 & 221 & 364 & 342 & 278 \\
\hline Rainfall & & 210 & 90 & 83 & 113 & 119 & 52 & 83 & 62 & 139 & 111 & 106 \\
\hline Irrigation & & 112 & 173 & 116 & 188 & 174 & 149 & 189 & 159 & 224 & 231 & 172 \\
\hline
\end{tabular}

${ }^{1}$ Week in which the cover crops were sown. 
help ensure that sufficient quantities of water would be available for the irrigation of the grapevines during the growing season, the irrigation of the cover crops had to be stopped prematurely five and six weeks before the end of August 2001 and 2002, respectively. As rainfall also varied considerably between years, different years in this study actually presented different scenarios (treatments) with regard to plant water availability.

The cover crops were sown annually during April, with the exception of 1993 (sowing was done in the first week of May), at seeding rates suggested by Fourie et al. (2001). Seedbed preparation was done with a disc harrow approximately six weeks before the seeding date. After sowing by hand, the seeds were covered using a cultivator. During 1995 and 1997, with the exception of pink Seradella in the latter year, no seeds were sown in the $A B$ treatments, while during 1999 this management practice was restricted to grazing vetch and the two medics (Table 3 ).

TABLE 3

The effect of five cover crop management practices, applied selectively to eight cover crop species, on the dry matter production (DMP), measured at the end of August.

\begin{tabular}{|c|c|c|c|c|c|c|c|c|c|c|c|}
\hline \multirow{2}{*}{ Treatment } & \multicolumn{11}{|c|}{ DMP (t/ha) } \\
\hline & 1993 & 1994 & 1995 & 1996 & 1997 & 1998 & 1999 & 2000 & 2001 & 2002 & Average \\
\hline $\begin{array}{l}\text { Secale cereale L. v. Henog } \\
\text { (rye), } \mathrm{BB}^{1}, \mathrm{SF}^{2} \text {. }\end{array}$ & 3.94 & 4.28 & 1.71 & 4.06 & 2.92 & 1.01 & 2.56 & 2.67 & 4.82 & 4.97 & 3.29 \\
\hline $\begin{array}{l}\text { Secale cereale L. v. Henog } \\
\text { (rye) } \mathrm{AB}^{3}, \mathrm{SF} \text {. }\end{array}$ & 2.10 & 3.24 & 0.09 & 3.60 & $1.00^{8}$ & 1.32 & 3.25 & 2.38 & 4.35 & 4.04 & 2.54 \\
\hline 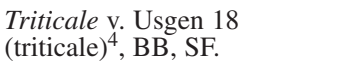 & 2.10 & 2.37 & 0.69 & 3.02 & 2.03 & 0.63 & 0.22 & 0.02 & 0.15 & 0.96 & 1.22 \\
\hline $\begin{array}{l}\text { Triticale v. Usgen } 18 \\
\text { (triticale) })^{5}, \mathrm{AB}, \mathrm{SF} \text {. }\end{array}$ & 2.46 & 1.72 & $0.24^{8}$ & 2.12 & $0.18^{8}$ & 0.58 & 0.79 & 0.78 & 2.11 & 1.98 & 1.29 \\
\hline $\begin{array}{l}\text { Avena sativa L. v. Overberg } \\
\text { ('Overberg' oats), BB, SF. }\end{array}$ & 0.80 & 1.78 & 0.42 & 2.68 & 2.04 & 0.97 & 1.67 & 1.58 & 2.58 & 2.90 & 1.74 \\
\hline $\begin{array}{l}\text { Avena sativa L. v. Overberg } \\
\text { ('Overberg' oats), AB, SF. }\end{array}$ & 0.67 & 2.14 & $0.01^{8}$ & 1.92 & $0.06^{8}$ & 0.82 & 1.28 & 1.18 & 1.70 & 2.66 & 1.24 \\
\hline $\begin{array}{l}\text { Avena strigosa L. v. Saia } \\
\text { ('Saia' oats), BB, SF. }\end{array}$ & 1.54 & 3.08 & 0.87 & 3.88 & 3.96 & 0.83 & 2.06 & 1.31 & 4.45 & 3.55 & 2.55 \\
\hline $\begin{array}{l}\text { Avena strigosa L. v. Saia } \\
\text { ('Saia' oats), AB, SF. }\end{array}$ & 1.63 & 2.46 & $0.28^{8}$ & 4.14 & $1.01^{8}$ & 0.82 & 2.31 & 2.02 & 5.37 & 2.86 & 2.25 \\
\hline $\begin{array}{l}\text { Medicago truncatula } \\
\text { Gaertn. v. Parabinga } \\
\text { ('Parabinga' medic), BB, SF. }\end{array}$ & 2.77 & 2.16 & 0.30 & 2.13 & 2.07 & 1.16 & 2.09 & 1.09 & 3.14 & 2.28 & 1.92 \\
\hline $\begin{array}{l}\text { Medicago truncatula } \\
\text { Gaertn v. Parabinga } \\
\text { ('Parabinga' medic), AB, SF. }\end{array}$ & 3.66 & 2.50 & $0.37^{8}$ & 2.25 & $1.23^{8}$ & 0.94 & $1.64^{8}$ & 1.21 & 2.49 & 1.96 & 1.83 \\
\hline $\begin{array}{l}\text { Medicago truncatula } \\
\text { Gaertn v. Paraggio } \\
\text { ('Paraggio' medic), BB, SF. }\end{array}$ & 4.22 & 2.82 & 0.58 & 3.39 & 3.94 & 0.91 & 4.21 & 0.88 & 4.79 & 2.44 & 2.82 \\
\hline $\begin{array}{l}\text { Medicago truncatula } \\
\text { Gaertn v. Paraggio } \\
\text { ('Paraggio' medic), AB, SF. }\end{array}$ & 3.00 & 3.07 & $0.17^{8}$ & 2.77 & $1.39^{8}$ & 0.35 & $1.25^{8}$ & 0.87 & 4.88 & 2.29 & 2.00 \\
\hline $\begin{array}{l}\text { Ornithopus sativus } \\
\text { L. v. Emena } \\
\text { (pink Seradella), BB, SF. }\end{array}$ & 5.02 & 2.21 & 1.03 & 4.61 & 3.40 & 1.54 & 3.78 & 1.01 & 4.88 & 4.08 & 3.06 \\
\hline $\begin{array}{l}\text { Ornithopus sativus } \\
\text { L. v. Emena } \\
\text { (pink Seradella), AB, SF. }\end{array}$ & 4.49 & 2.07 & $0.05^{8}$ & 3.76 & 4.99 & 1.07 & 2.72 & 0.86 & 5.99 & 3.73 & 2.97 \\
\hline $\begin{array}{l}\text { Vicia dasycarpa Ten. } \\
\text { (grazing vetch), BB, SF. }\end{array}$ & 2.69 & 3.66 & 0.58 & 2.92 & 2.79 & 0.80 & 1.66 & 0.82 & 4.11 & 2.83 & 2.29 \\
\hline $\begin{array}{l}\text { Vicia dasycarpa Ten. } \\
\text { (grazing vetch), AB, SF. }\end{array}$ & 3.01 & 2.55 & $1.01^{8}$ & 3.15 & $1.71^{8}$ & 1.40 & $0.62^{8}$ & 1.17 & 3.57 & 2.73 & 2.09 \\
\hline $\begin{array}{l}\text { Avena strigosa } \mathrm{L} \text {. v. Saia } \\
\text { ('Saia' oats), BB, NF'. }\end{array}$ & 0.90 & .98 & 0.27 & 0.61 & 0.40 & 0.22 & 0.37 & 0.43 & 0.43 & 0.89 & 0.55 \\
\hline $\begin{array}{l}\text { Avena strigosa L. v. Saia } \\
\text { ('Saia' oats), BB, SF x } 2 \text {. }\end{array}$ & 2.12 & 3.59 & 1.01 & 3.70 & 4.13 & 1.28 & 2.34 & 2.02 & 4.60 & 4.38 & 2.92 \\
\hline $\begin{array}{l}\text { Vicia dasycarpa Ten. } \\
\text { (grazing vetch), BB, NF. }\end{array}$ & 2.48 & 2.83 & 0.81 & 3.01 & 2.35 & 0.58 & 1.67 & 0.98 & 2.50 & 2.85 & 2.01 \\
\hline $\begin{array}{l}\text { Vicia dasycarpa Ten. } \\
\text { (grazing vetch), BB, SF x } 2\end{array}$ & 2.71 & 3.11 & 0.59 & 3.14 & 3.10 & 0.56 & 1.44 & 1.15 & 2.55 & 3.68 & 2.20 \\
\hline $\begin{array}{l}\text { Avena strigosa L. v. Saia } \\
\text { ('Saia' oats), MC', SF. }\end{array}$ & 1.48 & 2.68 & 0.64 & 2.26 & 3.53 & 0.64 & 2.10 & 1.75 & 4.05 & 2.75 & 2.19 \\
\hline $\begin{array}{l}\text { Vicia dasycarpa Ten. } \\
\text { (grazing vetch), MC, SF. }\end{array}$ & 3.49 & 3.31 & 0.38 & 2.52 & 2.73 & 0.47 & 0.87 & 0.82 & 3.40 & 2.29 & 2.03 \\
\hline Weeds, MC, SF (Control). & 0.48 & 1.65 & 1.74 & 2.05 & 0.81 & 0.14 & 0.81 & 0.34 & 1.00 & 1.35 & 1.14 \\
\hline $\operatorname{LSD}(\mathrm{p} \leq 0.05)$ & 1.09 & 0.68 & 0.66 & 0.58 & 1.91 & 0.67 & 1.2 & 0.76 & 1.99 & 1.49 & 0.61 \\
\hline
\end{tabular}

${ }^{1} \mathrm{BB}=$ full surface chemical control before bud break. ${ }^{2} \mathrm{SF}=$ standard amount of fertilizer applied. ${ }^{3} \mathrm{AB}=$ full surface chemical control at the end of November.

${ }^{4}$ Triticale v. Usgen replaced by Lolium perenne L. v. Derby Cochise from 1999. ${ }^{5}$ Triticale v. Usgen replaced by Medicago mixture from 1999.

${ }^{6} \mathrm{NF}=$ no fertilizer applied in working row. ${ }^{7} \mathrm{MC}=$ chemical control in vine row, mechanical control in working row. ${ }^{8} \mathrm{Cover}$ crop left to re-establish. 


\section{Experimental procedure}

Twenty-three treatments were applied (Table 3). Two cover crop management practices, namely chemical control before bud break (BB) and chemical control at the end of November (AB), were applied to eight cover crop species. Two treatments in which Avena strigosa L. v. Saia ('Saia' oats) and Vicia dasycarpa Ten. (grazing vetch) were controlled mechanically during bud break were also applied. These eighteen treatments received $30 \mathrm{~kg} \mathrm{P}$ at the end of February (just before seedbed preparation), $30 \mathrm{~kg} \mathrm{~K}$ and $14 \mathrm{~kg} \mathrm{~N}$ during the second week of April (just after the cover crops were sown), as well as $28 \mathrm{~kg} \mathrm{~N}$ at the two-to-four-leaf stage of the grass cover crops. Two weeks after bud break (late September), $30 \mathrm{~kg} \mathrm{~K}$ and $42 \mathrm{~kg} \mathrm{~N}$ were applied. For the purpose of the study, the latter will be referred to as the standard amount of fertilizer (SF). In the case of the $\mathrm{N}$-fixing broadleaf cover crops, the $\mathrm{N}$ was applied only to the vine row. In addition to these eighteen treatments, four treatments were also applied in which the amount of fertilizer applied to 'Saia' oats and grazing vetch deviated from SF. In two of these treatments (one for each species) all applications were restricted to the vine row up to the 1995/96 season, after which no fertilizer was applied (NF). The other two treatments received double the standard amount of fertilizer (SF x 2). A mechanically cultivated control in which no cover crop was sown and in which SF was applied was included in the trial. The different weed control actions were executed twice per year, namely before bud break of the grapevines (first week of September) and when the berries reached pea size (end of November).

\section{Measurements}

Dry matter production (DMP) of both the cover crops and the associated weeds was determined at the end of August (just before bud break of the grapevines) and the end of November (pea-size berries). DMP was measured as described by Fourie et al. (2001).

To determine the number of viable seeds present in the top 100 $\mathrm{mm}$ of the soil, including the seeds on the soil surface, an area of $0.25 \mathrm{~m}^{2}$ was sampled at the end of February (six weeks before the seeding date). The soil was air-dried and sieved through an 850micron sieve, to separate the organic matter and cover crop seeds from the soil. The cover crop seeds were separated from the organic matter by hand. The viability of the seeds was determined by means of the "between paper" method prescribed by the International Seed Testing Association (1999).

\section{Statistical procedures}

Twenty-three treatment combinations were randomly allocated within each of three blocks. The treatment design was a $(8 \times 2)+7$ factorial with factors eight cover crops, two management practices, as well as seven other practices. The experiment was repeated for 10 consecutive seasons (years). The size of each unit (plot) was $108 \mathrm{~m}^{2}$. All variables were measured at random sites within each experiment unit at the end of August and the end of November. Analyses of variance were performed separately for each season using SAS (SAS, 1990). Student's $t$ least significant difference (LSD) was calculated at a 5\% significance level to compare treatment means. The Shapiro-Wilk test was performed to test for non-normality (Shapiro \& Wilk, 1965).

\section{RESULTS AND DISCUSSION \\ DMP of cover crops}

The DMP of the cover crops, as measured at the end of August, was (for the duration of the study) less than that reported by Fourie et al. (2001) under similar edaphic conditions (Table 3). In the study by Fourie et al. (2001), a DMP in excess of five t/ha was achieved at the end of August, with the cover crops receiving weekly irrigations of $18 \mathrm{~mm}$ during the first 10 weeks after sowing, followed by $18 \mathrm{~mm}$ of water every fortnight - totaling 270 $\mathrm{mm}$ (rainfall, as well as irrigation applied) from the beginning of April to the end of August. The performance of the cover crops in the present study varied considerably between seasons (Table 3 ). This could be attributed to, inter alia, seeding date (1993), but to a greater extent to a continuous $(1995,1998$ \& 2000) or periodic (1994, 1996, 1997 \& 1999 to 2002) shortage of rainfall and irrigation water during winter (Table 3 ), the latter being caused by restrictions in the water supply, preventing the application of the irrigation schedule suggested by Fourie et al. (2001).

Water deficits during six of the first ten weeks after sowing, followed by dry periods lasting up to six weeks (Table 2), limited the total amount of water received during 1995, 1998 and 2000 to between $49 \mathrm{~mm}$ and $143 \mathrm{~mm}$ less than the amount deemed necessary for sufficient cover crop growth (Van Bosch \& Pieterse, 1995; Fourie et al., 2001; Anonymous, 2003). This limitation caused extremely poor cover crop performance (Table 3). Although the cover crops were sown late in 1993 (Table 3), the relatively high winter rainfall and irrigation that could be applied regularly during the dry periods (Table 2) resulted in the cover crops, with the exception of Triticale v. Usgen 18 (triticale) and the two Avena (oat) species, producing acceptable amounts of dry matter (Table 3). Secale cereale L v. Henog (rye) and the two oat species produced more dry matter during 1994 compared with 1993 (Table 3), although they received less water (Table 2). This could be attributed to the growing period in 1994 being three weeks longer than that of 1993 (Table 3) and supported the results of Fourie et al. (2001). This indicated the importance of establishing these species early in April under full surface irrigation. The dry spell that occurred during 1994 (in the seventh to the eleventh week after planting) reduced the DMP of the two medic species and pink Seradella compared with that of 1993 (Table 2), despite the longer-growing season. Although the cover crops received water at least once a week up to 15 weeks after planting during the winter of 2001 (Table 2), the following dry spell of five weeks seemed to restrict the species, with the exception of pink Seradella and 'Saia' oats, to a DMP of less than five t/ha (Table 3 ). The dry spell of six weeks experienced at the end of the winter of 2002 (Table 2) had a pronounced negative effect on the DMP of Saia oats and Medicago truncatula Gaertn. v. Paraggio ('Paraggio' medic). Although the cover crops received less water during 1996 than during 2002 (Table 2), the DMP was similar, with 'Paraggio' medic performing better during the first-mentioned season (Table 3). This could be attributed to the fact that the interval between rainfall events or irrigations during the winter of 1996 did not exceed a fortnight. It seems, therefore, that the interval between irrigations or rainfall events throughout winter should preferably not be allowed to exceed two weeks.

Rye and pink Seradella were, on average, the two most successful species (Table 3). This finding is in accordance with the find- 
ings of Gladstones \& McKeown (1977) and Williams \& De Lautour (1975), namely that Ornithopus sativus is capable of performing well on low fertility sands. The average DMP of 'Paraggio' medic and 'Saia' oats at the end of August was not significantly less than that of the first-mentioned species (Table 3). These two species could, therefore, also be considered for cover crop management in this region. Although the average DMP of 'Paraggio' medic was less than that reported by Fourie (2001), it was similar to that produced on a sandy soil, under cool winter conditions and an average winter rainfall of $754 \mathrm{~mm}$ (Bolland, 1997). This indicated that 'Paraggio' medic is well adapted to the climate of the Olifants River Valley. On average, grazing vetch did not perform as well as the above-mentioned species (Table 3), but showed the ability to produce in excess of four tons of dry matter per ha, if it received approximately $18 \mathrm{~mm}$ of water a week (Table 2).

The average DMP of Saia oats BB/NF was only $21.6 \%$ compared with that of 'Saia' oats BB/SF and significantly lower than the DMP of the weeds in the control, indicating that fertilizer application during the establishment of a grain species on these infertile sandy soils is essential (Table 3). Doubling the quantity of fertilizer applied increased the average DMP of Saia oats $\mathrm{BB} / \mathrm{SFx} 2$ by $14,5 \%$, compared to what has been obtained with the $\mathrm{BB} / \mathrm{SF}$ treatment. The standard amount of fertilizer applied to 'Saia' oats in this study was similar to the $\mathrm{N}$ and $\mathrm{P}$ applied to the species on a heavy clay soil with high organic matter (Assefa \& Ledin, 2001). This also indicated that SF should be increased to maximise DMP on the sandy soils of the Olifants River Valley. Doubling the quantity of fertilizer applied during establishment of 'Saia' oats, however, seems luxurious, as it did not significantly increase the DMP of Saia oats. Irrespective of the quantity of fertilizer applied, the DMP of the BB treatments of grazing vetch did not differ significantly. It seemed, therefore, that $\mathrm{P}$ and $\mathrm{K}$ at levels of $10 \mathrm{mg} / \mathrm{kg}$ and $78 \mathrm{mg} / \mathrm{kg}$, respectively, in the top $300 \mathrm{~mm}$ soil layer, supplied the needs of grazing vetch. This was much lower than the $15.5 \mathrm{mg} / \mathrm{kg}-23.2 \mathrm{mg} / \mathrm{kg}$ P deemed necessary for near maximum yields by grazing vetch on a Manawatu fine sandy loam (De Ruiter, 1981).

All the species, except Medicago truncatula Gaertn. v. Parabinga ('Parabinga' medic), showed increased DMP from the end of August to the end of November (Table 4), depending on either seeding date or the amount and frequency of water received from April to August (Table 2). Rye, triticale and 'Paraggio' medic produced extra dry matter during 1998 only (Table 4), despite being sown early in comparison to the other seasons (Table 2). This additional growth from September to November (Table 4) was triggered by the irrigation during the growing season. The growth of these three species was retarded during the winter of 1998 because they received less water than in 1993, 1994, $1997 \& 2001$ (Table 2). The two oat species produced additional fibre from September to November during 1993 and 1998 (Table 4), because they were sown late and did not receive sufficient water to complete their life cycle (Table 2), respectively. Pink Seradella produced additional fibre from September to November (Table 4) if the total amount of water received regularly during winter was less than $300 \mathrm{~mm}$ (Table 2). Grazing vetch kept on growing after the end of August, except in 2001 (Table 4). It seemed that the luxurious water supply each week from the seeding date up to 15 weeks after planting during 2001(Table 2) enabled the species to complete growth by the end of August (Table 4).

\section{Potential of species to re-establish themselves}

Grazing vetch was the only species capable of producing an amount of viable seeds that exceeded the seeding density used in the treatments in which the species were sown annually (Fig. 1). This resulted in the DMP of grazing vetch AB/SF being $174.1 \%$ compared with that of grazing vetch $\mathrm{BB} / \mathrm{SF}$ at the end of August 1995 (Table 3), indicating that the species had the potential to reestablish successfully in the short term. In the medium term (end of August 1997), however, the DMP of grazing vetch AB/SF was only $61.3 \%$ compared with that of grazing vetch $\mathrm{BB} / \mathrm{SF}$, although the number of viable seeds present in the top $100 \mathrm{~mm}$ of the soil, including the seeds on the soil surface of the first-mentioned treatment, still exceeded the seeding density used in the BB/SF treatment (Fig. 1). The reason for this is not known. The poor growth of grazing vetch in the AB/SF treatment during 1997 and 1998 (Table 3), as well as the fact that approximately $17 \%$ of the seeds in the soil were damaged annually, could have resulted in the decline in the number of seeds over these two seasons

\section{TABLE 4}

Percentage change in dry matter production (DMP) of the different species from the end of August to the end of November, as determined in the treatments in which chemical control was applied at the end of November 1993 to 1998 and in mid-October 1999 to 2002.

\begin{tabular}{|c|c|c|c|c|c|}
\hline \multirow{2}{*}{ Treatments } & \multicolumn{5}{|c|}{ Change in DMP from the end of August to the end of November } \\
\hline & 1993 & 1994 & 1996 & 1998 & $2001^{1}$ \\
\hline Secale cereale L. v. Henog (rye) & -22 & -48 & -21 & 47 & -0.1 \\
\hline Triticale v. Usgen (triticale) & -7 & -28 & -49 & 129 & $\mathrm{NA}^{2}$ \\
\hline Avena sativa L. v. Overberg ('Overberg' oats) & 72 & -9 & -7 & 66 & -24 \\
\hline Avena strigosa L. v. Saia ('Saia' oats) & 67 & 7 & -42 & 76 & -41 \\
\hline Vicia dasycarpa Ten. (grazing vetch) & 15 & 35 & 18 & 114 & -32 \\
\hline Medicago truncatula Gaertn v. Parabinga ('Parabinga' medic) & -59 & -2 & -50 & -22 & -65 \\
\hline Medicago truncatula Gaertn v. Paraggio ('Paraggio' medic) & -49 & -20 & -26 & 160 & -20 \\
\hline Ornithopus sativus L. v. Emena (pink Seradella) & 2 & 52 & -50 & 50 & -57 \\
\hline
\end{tabular}

${ }^{1}$ Cover crops controlled chemically mid-October.

${ }^{2}$ Triticale v. Usgen replaced by mixture of Medicago species. 
(Fig. 1). This resulted in the re-establishment of the species during 1999 being only $37.3 \%$ successful (Table 3). It should therefore be possible to cut back at least $40 \%$ on the seeding density of grazing vetch after two seasons, if it was left to ripen its seeds.

'Parabinga' medic showed potential to re-establish itself, as indicated by the continuous increase in the number of viable seeds present in the top $100 \mathrm{~mm}$ of the soil including the seeds on the soil surface of the AB/SF treatment over time (Fig. 2), and the corresponding increase in the DMP at the end of August (Table
$3)$. The species could not, however, produce enough seeds to reestablish itself successfully over a period of five years and would not likely do so in the long term under similar edaphic conditions (Fig. 2). The AB/SF treatment of 'Paraggio' medic showed a similar trend. Although the amount of water the medic species received in the present study exceeded that deemed necessary for re-establishment (Tadmor et al., 1971; Tadmor et al., 1974), the seed density of the two medic species never reached the amounts deemed necessary for successful re-establishment (Carter \&

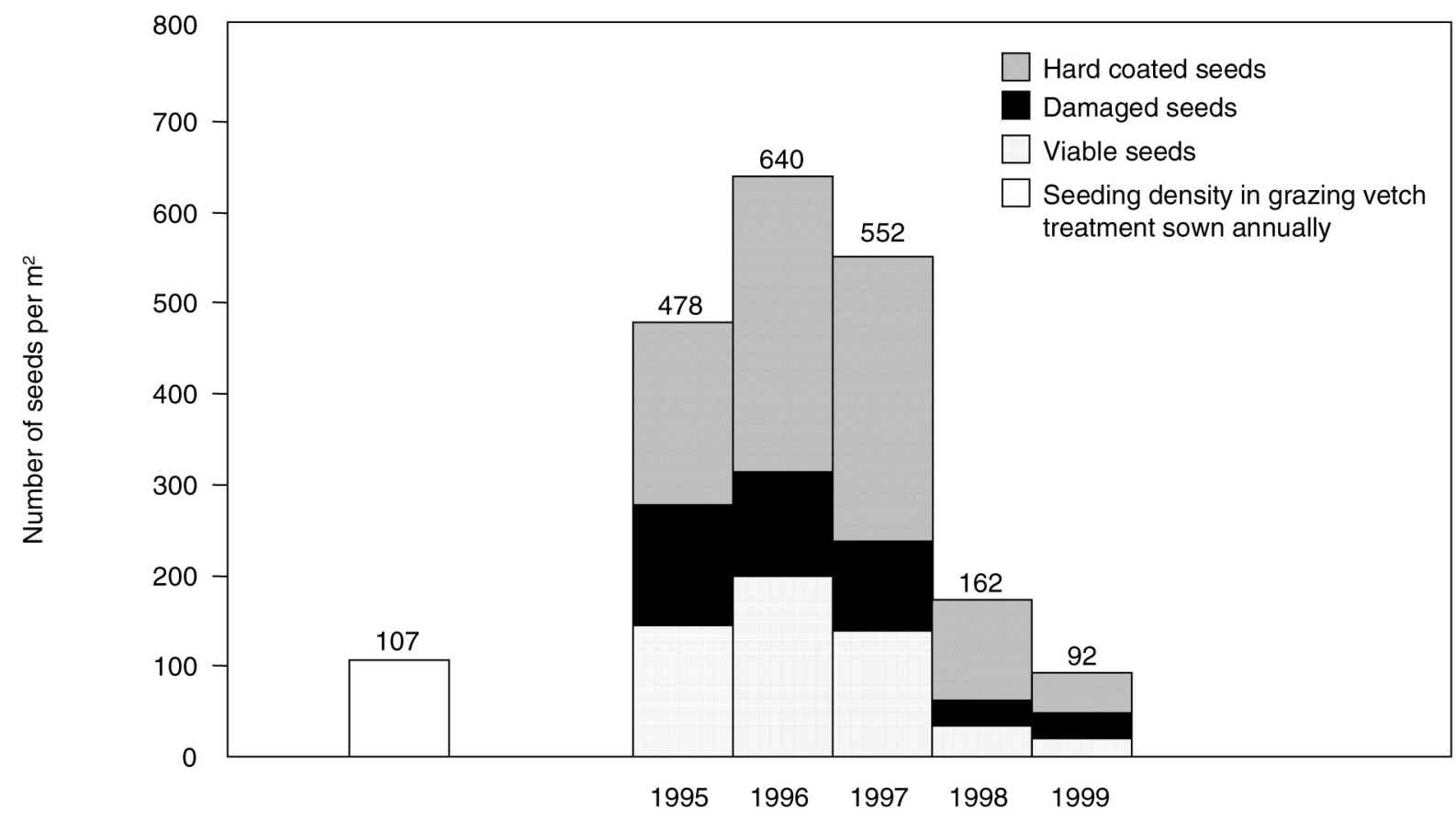

FIGURE 1

The number of seeds produced by Vicia dasycarpa over a period of five years on a sandy soil in the Olifants River Valley, if controlled chemically at the end of November.

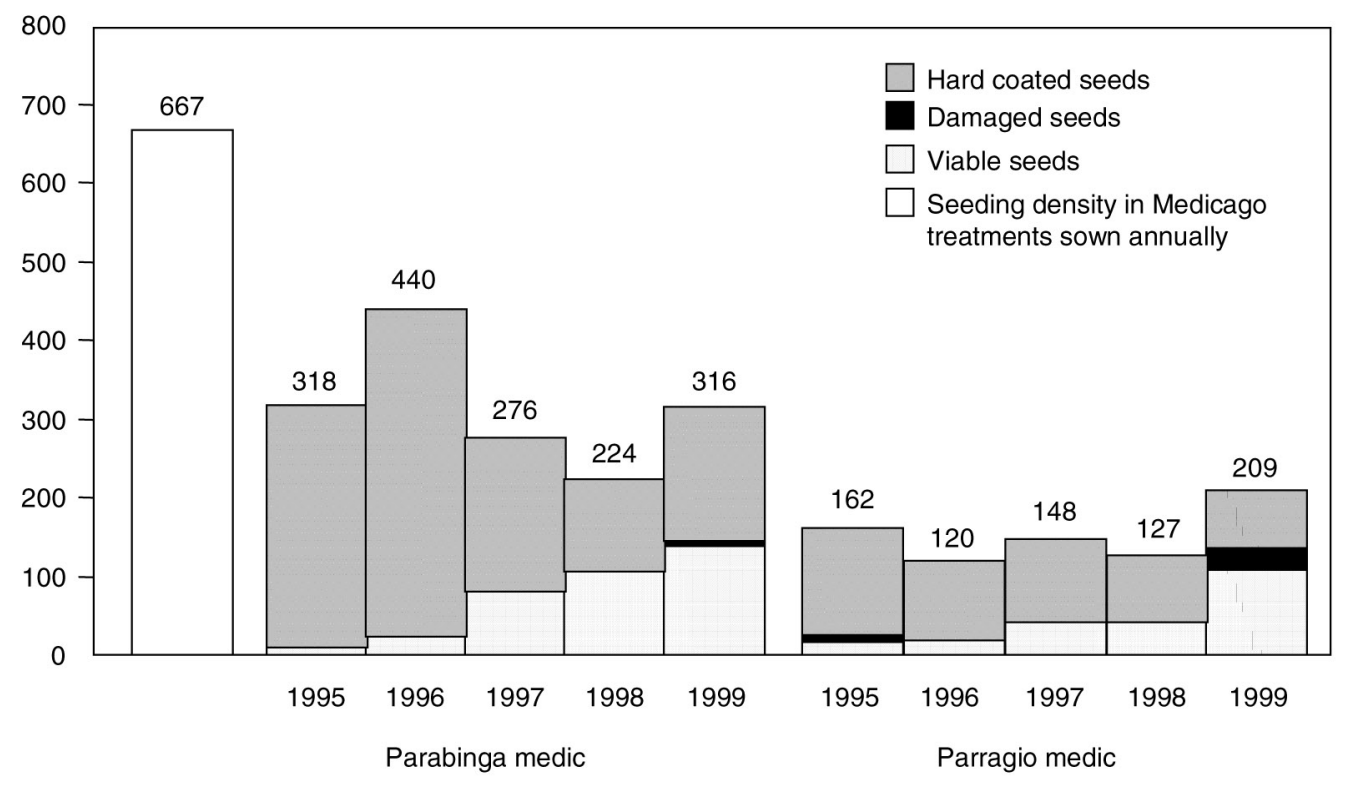

FIGURE 2

The number of seeds produced by Medicago truncatula v. Parabinga and M. truncatula v. Paraggio over a period of five years on a sandy soil in the Olifants River Valley, if controlled chemically at the end of November. 
Lake, 1985). The number of viable seeds present in the top 100 $\mathrm{mm}$ of the soil, including the seeds on the soil surface (Fig. 2), as well as the DMP at the end of August (Table 3), indicated that it should be possible to cut back on the seeding density of both species by approximately $20 \%$ after they had been sown for five consecutive years and left to ripen their seeds.

The grain species did not re-establish successfully during both 1995 and 1997 (Table 3) as only a small number of undamaged, viable seeds were present in the top $100 \mathrm{~mm}$ of the soil, including the seeds on the soil surface (Table 5). Although the number of seeds harvested from the above-mentioned soil layer in the $\mathrm{AB} / \mathrm{SF}$ treatment of Avena sativa L. v. Overberg ('Overberg' oats) during 1995 and 1997 was as high as $55 \%$ and $61 \%$ of the seeding density used in the $\mathrm{BB} / \mathrm{SF}$ treatment $\left(250\right.$ seeds per $\left.\mathrm{m}^{2}\right)$, respectively, less than $3 \%$ of the seeds were viable (Table 5). This resulted in practically no cover crop growth (Table 3 ). Rye produced $22 \%$ of the seeding density used in the corresponding $\mathrm{BB} / \mathrm{SF}$ treatment (304 seeds per $\mathrm{m}^{2}$ ) during 1997 (Table 4). This resulted in a DMP of one t/ha at the end of August 1997, which was significantly less than that of the corresponding BB/SF treatment and only $23 \%$ more than that produced by the weeds in the control (Table 3). A similar result was achieved with 'Saia' oats during 1997, although the number of viable seeds per $\mathrm{m}^{2}$ was less than that of rye (Table 5) and only $10 \%$ of the amount sown in the $\mathrm{BB} / \mathrm{SF}$ treatment $\left(468\right.$ seeds per $\mathrm{m}^{2}$ ). The number of viable seeds present in the top $100 \mathrm{~mm}$ of the soil (including the seeds on the soil surface) of the $\mathrm{AB} / \mathrm{SF}$ treatments of the grain species during 1999 indicated that no build up of viable seeds occurred (Table 4) and that these species would not be able to re-establish under similar edaphic conditions. The grain species were, therefore, sown in the $\mathrm{AB} / \mathrm{SF}$ treatments at the same seeding density used for the BB treatments from 1999 onwards.

No seeds could be found in the top $100 \mathrm{~mm}$ of soil (including the soil surface) of the pink Seradella AB/SF treatment from 1995 to 1999 (Table 5). The species, being soft-seeded, could have resulted in all the seeds germinating because of irrigation applied regularly during December and January. Pink Seradella was, therefore, sown in the AB/SF treatment at the same seeding density used for the BB/SF treatment from 1997 onwards.

\section{Weed control}

The suppression of the winter growing weeds by the cover crops varied considerably between seasons and in most years the weed stand in the cover crop treatments did not differ significantly from that of the mechanically cultivated control (data not shown). This could mainly be attributed to the overall weed growth being poor during winter. The cover crops, however, suppressed the winter growing weeds significantly during 1996, 1999 and 2001 compared with the control (Table 6), indicating that it could compete effectively with the winter growing weeds in the region. The level of weed suppression achieved with the different species compared well with that reported by Fourie et al. (2001). Effectively suppressing the winter growing weeds may result in a reduction in the dosage of herbicide applied at the end of August and may minimise the negative effects caused by weeds, such as the harbouring of nematodes and mealy bug during winter.

The correlation between the DMP of the cover crops and the weeds is shown in Table 7. An increase in the growth of pink Seradella had the most significant negative impact on weed growth during winter. The growth of grazing vetch, 'Overberg' oats and 'Paraggio' medic, in order of merit, also had a significantly negative impact on weed growth during winter.

The growth of the summer growing weeds in the control from the end of August to the end of November was on average as low as 0.28 ton/ha (data not shown). Despite this, the correlation between the DMP of grazing vetch and weed dry matter, although not strong, was statistically significant at the $3 \%$ level.

The results indicated that grazing vetch was the only species for which an increase in DMP during winter would result in improved weed suppression during both winter and summer.

\section{TABLE 5}

The number of seeds produced by the four grain species and Ornithopus sativus L. v. Emena over a period of four years on a sandy soil in the Olifants River Valley, if left to ripen its seeds.

\begin{tabular}{|c|c|c|c|c|c|c|c|c|c|c|c|c|}
\hline \multirow{3}{*}{ Species } & \multicolumn{12}{|c|}{ Number of seeds per $\mathbf{m}^{2}$} \\
\hline & \multicolumn{3}{|c|}{1995} & \multicolumn{3}{|c|}{1996} & \multicolumn{3}{|c|}{1997} & \multicolumn{3}{|c|}{1998} \\
\hline & Total & Viable & Damaged & Total & Viable & Damaged & Total & Viable & Damaged & Total & Viable & Damaged \\
\hline $\begin{array}{l}\text { Secale cereale } \\
\text { L. v. Henog (rye) }\end{array}$ & 62 & 8 & 54 & 0 & 0 & 0 & 164 & 67 & 97 & 1 & 1 & 0 \\
\hline $\begin{array}{l}\text { Triticale v. Usgen } \\
18 \text { (triticale) }\end{array}$ & 22 & 4 & 18 & 0 & 0 & 0 & 4 & 3 & 1 & 8 & 5 & 3 \\
\hline $\begin{array}{l}\text { Avena sativa L. v. Overberg } \\
\text { ('Overberg' oats) }\end{array}$ & 138 & 0 & 138 & 36 & 0 & 36 & 152 & 4 & 148 & 2 & 1 & 1 \\
\hline $\begin{array}{l}\text { Avena strigosa L. v. Saia } \\
\text { ('Saia' oats) }\end{array}$ & 34 & 4 & 30 & 0 & 0 & 0 & 82 & 46 & 36 & 1 & 1 & 0 \\
\hline $\begin{array}{l}\text { Ornithopus sativus } \\
\text { L. v. Emena (pink Seradella) }\end{array}$ & 0 & 0 & 0 & 0 & 0 & 0 & $\mathrm{NA}^{1}$ & NA & NA & NA & NA & NA \\
\hline $\operatorname{LSD}(\mathrm{p} \leq 0.05)$ & 62 & 22 & 35 & 138 & 46 & 12 & 82 & 26 & 31 & 61 & 15 & 12 \\
\hline
\end{tabular}

${ }^{1} \mathrm{NA}=$ Not applicable 


\section{TABLE 6}

The effect of five cover crop management practices, applied selectively to eight cover crop species, as well as a mechanically cultivated soil, on the dry matter production (DMP) of winter growing weeds, measured end of August 1996, 1999 and 2001.

\begin{tabular}{|c|c|c|c|}
\hline \multirow{2}{*}{ Treatment } & \multicolumn{3}{|c|}{ DMP (t/ha) } \\
\hline & 1996 & 1999 & 2001 \\
\hline Secale cereale L. v. Henog (rye), $\mathrm{BB}^{1}, \mathrm{SF}^{2}$. & 0.56 & 0.30 & 0.17 \\
\hline Secale cereale $\mathrm{L}$ (rye), $\mathrm{AB}^{3}, \mathrm{SF}$. & 0.20 & 0.05 & 0.27 \\
\hline Triticale v. Usgen 18 (triticale) $)^{4}, \mathrm{BB}, \mathrm{SF}$. & 0.72 & 0.84 & 0.22 \\
\hline Triticale v. Usgen 18 (triticale) ${ }^{5}, \mathrm{AB}, \mathrm{SF}$. & 0.24 & 0.75 & 0.23 \\
\hline Avena sativa L. v. Overberg ('Overberg' oats), BB, SF. & 0.34 & 0.43 & 0.01 \\
\hline Avena sativa L. v. Overberg ('Overberg' oats), AB, SF. & 0.50 & 0.52 & 0.03 \\
\hline Avena strigosa L v. Saia ('Saia' oats), BB, SF. & 0.10 & 0.32 & 0.08 \\
\hline Avena strigosa L. v. Saia ('Saia' oats), AB, SF. & 0.21 & 0.30 & 0.04 \\
\hline Medicago truncatula Gaertn. v. Parabinga ('Parabinga' medic), BB, SF. & 0.77 & 0.35 & 0.14 \\
\hline Medicago truncatula Gaertn. v. Parabinga ('Parabinga' medic), AB, SF. & 0.20 & 0.24 & 0.05 \\
\hline Medicago truncatula Gaertn. v. Paraggio ('Paraggio' medic), BB, SF. & 0.50 & 0.19 & 0.07 \\
\hline Medicago truncatula Gaertn. v. Paraggio ('Paraggio' medic), AB, SF. & 0.32 & 0.52 & 0.30 \\
\hline Ornithopus sativus L. v. Emena (pink Seradella), BB, SF. & 0.27 & 0.47 & 0.02 \\
\hline Ornithopus sativus L. v. Emena (pink Seradella), AB, SF. & 0.94 & 0.50 & 0.05 \\
\hline Vicia dasycarpa Ten. (grazing vetch), BB, SF. & 0.36 & 1.11 & 0.01 \\
\hline Vicia dasycarpa Ten. AB, SF. & 0.17 & 0.58 & 0.03 \\
\hline Avena strigosa L. v. Saia ('Saia' oats), BB, $\mathrm{NF}^{6}$. & 0.06 & 0.07 & 0.00 \\
\hline Avena strigosa L. v. Saia ('Saia' oats), BB, SF x 2. & 0.36 & 0.62 & 0.10 \\
\hline Vicia dasycarpa Ten. (grazing vetch), BB, NF. & 0.20 & 0.58 & 0.09 \\
\hline Vicia dasycarpa Ten. (grazing vetch), BB, SF x 2 & 0.82 & 0.60 & 0.04 \\
\hline Avena strigosa L. v. Saia ('Saia’ oats), $\mathrm{MB}^{7}, \mathrm{SF}$. & 0.51 & 0.34 & 0.05 \\
\hline Vicia dasycarpa Ten. (grazing vetch), MB, SF. & 0.90 & 0.50 & 0.28 \\
\hline Weeds, MC ${ }^{7}, \mathrm{SF}$. (Control). & 2.05 & 1.81 & 1.00 \\
\hline $\operatorname{LSD}(p \leq 0.05)$ & 0.77 & 0.54 & 0.47 \\
\hline
\end{tabular}

${ }^{1} \mathrm{BB}=$ full surface chemical control before bud break. ${ }^{2} \mathrm{SF}=$ standard amount of fertilizer applied. ${ }^{3} \mathrm{AB}=$ full surface chemical control at the end of November.

${ }^{4}$ Triticale v. Usgen replaced by Lolium perenne L. v. Derby Cochise from 1999. ${ }^{5}$ Triticale v. Usgen replaced by Medicago mixture from 1999.

${ }^{6} \mathrm{NF}=$ no fertilizer applied in working row. ${ }^{7} \mathrm{MC}=$ chemical control in vine row, mechanical control in working row.

\section{TABLE 7}

Correlation between the dry matter production (DMP) of the cover crops and the weeds as measured at the end of August and the end of November over a period of 10 and 6 years, respectively.

\begin{tabular}{|c|c|c|c|c|c|}
\hline \multirow[b]{2}{*}{ Species } & \multirow[b]{2}{*}{$\begin{array}{l}\text { Number of } \\
\text { replications }\end{array}$} & \multicolumn{2}{|c|}{ End of August } & \multicolumn{2}{|c|}{ End of November ${ }^{1}$} \\
\hline & & $\begin{array}{c}\text { Pearson } \\
\text { correlation } \\
\text { coefficient }\end{array}$ & $\begin{array}{c}\text { Level of } \\
\text { significance }\end{array}$ & $\begin{array}{c}\text { Pearson } \\
\text { correlation } \\
\text { coefficient }\end{array}$ & $\begin{array}{c}\text { Level of } \\
\text { significance }\end{array}$ \\
\hline Secale cereale L. v. Henog (rye) & 12 & -0.28 & 0.23 & 0.01 & 0.95 \\
\hline Triticale v. Usgen 18 (triticale) & 12 & $-0.30^{1}$ & $0.20^{1}$ & -0.15 & 0.64 \\
\hline Avena sativa L. v. Overberg ('Overberg' oats) & 12 & -0.39 & 0.09 & -0.09 & 0.79 \\
\hline Avena. strigosa L. v. Saia ('Saia' oats) & 32 & -0.17 & 0.23 & -0.29 & 0.12 \\
\hline Vicia dasycarpa Ten. (grazing vetch) & 32 & -0.36 & 0.01 & -0.40 & 0.03 \\
\hline Medicago truncatula Gaertn. v. Parabinga ('Parabinga' medic) & 12 & -0.15 & 0.51 & -0.33 & 0.29 \\
\hline Medicago truncatula Gaertn. v. Paraggio ('Paraggio’ medic) & 12 & -0.38 & 0.10 & -0.29 & 0.36 \\
\hline Ornithopus sativus L. v. Emena (pink Seradella) & 12 & -0.53 & 0.02 & -0.25 & 0.43 \\
\hline
\end{tabular}

${ }^{1}$ Pearson correlation coefficient determined with six years data (1993 to 1998). 


\section{CONCLUSIONS}

Rye and pink Seradella were the least sensitive to water deficits and should, therefore, be the preferred species for cover crop management in the sandy soils of the semi-arid Olifants River Valley. 'Paraggio' medic and 'Saia' oats could also be considered for cover crop management in this region. Although grazing vetch did not perform on average as well as the above-mentioned species, it could also be considered for cover crop management during years in which the water quota for the region is not reduced.

Indications are that both the total amount of water and the frequency of irrigations and/or rainfall could affect the amount of dry matter produced by the cover crop species from April to August. The effect of different irrigation schedules on cover crop performance in this region should, therefore, be researched, to supply scientifically based guidelines for the optimal irrigation of cover crops on the sandy soils of the semi-arid Olifants River Valley.

It seemed that $\mathrm{P}$ and $\mathrm{K}$ at levels of $10 \mathrm{mg} / \mathrm{kg}$ and $78 \mathrm{mg} / \mathrm{kg}$, respectively, in the top 300-mm soil layer, supplied the needs of grazing vetch. 'Saia' oats, however, performed poorly if $30 \mathrm{~kg}$ P was not broadcast just before seedbed preparation, followed by an application of $30 \mathrm{~kg} \mathrm{~K}$ and $28 \mathrm{~kg} \mathrm{~N}$ just after the cover crops were sown and if $14 \mathrm{~kg} \mathrm{~N}$ was not applied at the two-to-four-leaf stage. Although it was luxurious to double the amount of fertilizer, the standard amount of fertilizer applied should be increased to maximise DMP. The specific amount should be determined by future research.

The cover crops (not controlled chemically at the end of August) did not produce additional dry matter from September to November if they regularly received sufficient amounts of water during winter. If sown late (first week in May), the two oats species, grazing vetch and, to a lesser extent, pink Seradella should produce additional fibre if not controlled chemically at the end of August. Grazing vetch would most likely produce additional fibre under these edaphic conditions, if not controlled chemically at the end of August. The preceding winter, therefore, determines the cover crop management practice that should be applied at the end of August.

The cover crops did not produce enough seeds to re-establish themselves successfully over a five-year period. It may, however, be possible to cut back on the seeding density of the two M. truncatula varieties (20\% after five seasons) and grazing vetch (40\% after two seasons) if the species are allowed to ripen their seeds.

All the cover crops showed the ability to compete effectively with the winter growing weeds.

\section{LITERATURE CITED}

Anonymous, 2003. Medic en klawer kultivars. Pamphlet, 1 pp. Agricol group, Box 300, Brackenfell 7560, Cape Town.

Archer, E. \& Booysen, J.H., 1987. Prieelstelsels vir wingerd. Wynboer Tegnies 21, 3-14.

Assefa, G. \& Ledin, I., 2001. The effect of variety, soil type and fertilizer on the establishment, growth, forage yield, quality and voluntary intake by cattle of oats and vetches cultivated in pure stands and mixtures. Anim. Feed Sci. Technol. 92, 95-111.

Bolland, M.D.A., 1997. Comparative phosphorous requirements of five annual medics. J. Plant Nutr. 20, 1029-1043.

Buckerfield, J.C. \& Webster, K.A., 1996. Earthworms, mulching, soil moisture and grape yields. Wine Indust. J. 11, 47-53.

Carter, E.D. \& Lake, A., 1985. Seed, seedling and species dynamics of grazed annual pastures in South Australia. Proc. XV Inter. Grassl. Cong., 654-656. In: Brahim, K. \& Smith, S.E., 1993. Annual medic establishment and the potential for stand persistence in southern Arizona. J. Range Manage. 46, 21-25.

De Ruiter, J.M., 1981. The phosphate response of eight Mediterranean annual and perennial legumes. N.Z. J. Agric. Res. 24, 33-36.

Fourie, J. C., Louw, P.J.E. \& Agenbag, G.A., 2001. Effect of seeding date on the performance of grasses and broadleaf species evaluated for cover crop management in two wine grape regions of South Africa. S. Afr. J. Plant Soil 18, 118-127.

Gladstones, J.S. \& McKeown, N.R., 1977. Seradella-a pasture legume for sandy soils. Journal of Agriculture (West Australia) 18, 11-14.

International Seed Testing Association, 1999. International rules for seed testing. Seed Sci. \& Technol. 27, Supplement, 174-182.

Louw, P.J.E. \& Bennie, A.T.P., 1992. Water runoff and soil erosion in vineyard soils. Austr. Grapegrower \& Winemaker Annual Technical Issue, 100-113.

SAS, 1990. SAS/STAT users guide, version 8, first edition, volume 2. SAS Institute Inc., Campus drive, Cary NC 27513.

Shapiro, S.S. \& Wilk, M.B., 1965. An analyses of variance test for normality (complete samples). Biometrika 52, 591-611.

Tadmor, N.H., Shanan, L. \& Evenari, M., 1971. "Runoff farming" in the desert. V. Persistence and yields of annual range species. Agron. J. 63, 91-95.

Tadmor, N.H., Eyal, E. \& Benjamin, R.W., 1974. Plant and sheep production on semi-arid annual grassland in Israel. J. Range Manage. 27, 427-432.

The Non-Affiliated Soil Analysis Work Committee, 1990. Handbook of standard soil testing methods for advisory purposes. Soil Sci Soc. South Africa, P.O. Box 30030, Sunnyside, Pretoria.

Van Bosch, J. \& Pieterse, P.A., 1995. Invloed van verskillende peile van besproeiing op die droëmateriaalopbrengs van verskeie rog-, korog- en hawer-kultivars in die Middelveld-bosveld van Transvaal. Toegepaste Plantwetenskap 9, 31-34.

Van Huyssteen, L., Van Zyl, J.L. \& Koen, A.P., 1984. The effect of cover crop management on soil conditions and weed control in a Colombar vineyard in Oudtshoorn. S. Afr. J. Enol. Vitic. 5, 7-17.

Williams, W.M. \& De Lautour, G., 1975. Potential of Seradella as a winter annual forage on sandy coastal soil. N. Z. J. Experimental Agric. 3, 339-342. 